\title{
IKZF1 NP_006051.1:p.N159Y
}

National Cancer Institute

\section{Source}

National Cancer Institute. IKZF1 NP 006051.1:p.N159Y. NCI Thesaurus. Code C158146.

A change in the amino acid residue at position 159 in DNA-binding protein Ikaros where asparagine has been replaced by tyrosine. 